\title{
A conditional Pax6 depletion study with no morphological effect on the adult mouse corneal epithelium
}

\author{
Natalie J. Dorà ${ }^{1,6}$, Martine Manuel ${ }^{2}$, Dirk-Jan Kleinjann ${ }^{3,7}$, David J. Price ${ }^{2}$, J. Martin Collinson ${ }^{4}$, Robert E. Hill ${ }^{3}$ \\ and John D. West ${ }^{5^{*}}$ (i)
}

\begin{abstract}
Objective: The corneas of heterozygous $\mathrm{Pax}^{+/-}$mice develop abnormally and deteriorate further after birth but it is not known whether the postnatal deterioration is predetermined by abnormal development. Our objective was to identify whether depletion of Pax6 in adult mice caused any corneal abnormalities, similar to those in $\mathrm{Pax}^{+/-}$mice, where Pax6 levels are low throughout development and adulthood. We used two tamoxifen-inducible, Cre-loxP experimental strategies to deplete Pax6 either ubiquitously or in a restricted range of cell types.

Results: In a preliminary study, ubiquitous depletion of Pax6 by tamoxifen treatment of E9.5 CAG-CreER ${ }^{T g /-} ;$ Pax $^{\text {fl/fl }}$ embryos affected eye development. Tamoxifen treatment of 12-week old, adult CAG-CreER ${ }^{T g /-}$;Pax6 $6^{f /+}$ and CAG$\mathrm{CreER}^{\mathrm{Tg} /-} ; \mathrm{Pax} 6^{\mathrm{fl} / \mathrm{l}}$ mice resulted in weak and/or patchy Pax6 immunostaining in the corneal epithelium but caused no corneal abnormalities. GFP staining in tamoxifen-treated CAG-CreER ${ }^{\mathrm{Tg} /}$; ;RCE:IoxP reporter mice was also patchy. We attribute patchy Pax6 staining to mosaic deletion of the Pax6 $6^{f l}$ allele, probably caused by mosaic CAG-CreER ${ }^{\text {Tg }}$ expression. In a parallel study, we treated adult Krt19-CreER ${ }^{T g /-} ; P_{a x 6^{f /+}}$ mice with tamoxifen to try to deplete Pax6 in limbal epithelial stem cells (LESCS) which replenish the corneal epithelium. However, Pax6 staining remained strong after a 12-week chase period so the Krt19-CreER ${ }^{T g /-}$ transgene may have failed to target LESCs.
\end{abstract}

Keywords: Cornea, Corneal epithelium, Cre-loxP, CAG-CreER, Krt19-CreER, Pax6, Mouse, Mosaic transgene expression

\section{Introduction}

The mouse cornea comprises an outer epithelium of 5-6 cell layers, a thick stroma and an inner endothelium. The corneal epithelium is maintained by limbal epithelial stem cells (LESCs), in the ring-shaped limbus, which is a transition zone between the corneal epithelium and the conjunctiva. The LESCs replace themselves and produce transient (or transit) amplifying cells (TACs) that move centripetally across the basal corneal epithelium and produce more differentiated daughter cells, which move apically, through the epithelial layers, and are shed from the surface [1].

\footnotetext{
*Correspondence: John.West@ed.ac.uk

${ }^{5}$ Centre for Integrative Physiology, Clinical Sciences, University of Edinburgh Medical School, Hugh Robson Building, George Square, Edinburgh EH8 9XD, UK

Full list of author information is available at the end of the article
}

The Pax6 gene, encoding the Pax6 transcription factor, is expressed in the brain, pancreas, olfactory system and several eye tissues, including the corneal and limbal epithelia, and is critical for eye development [2]. Low levels of Pax6 throughout development of heterozygous Pax $^{+/-}$mice cause small eyes, aniridia plus lens and corneal defects [3-8]. The newborn $\mathrm{Pax}^{+/-}$cornea has a thin epithelium and the adult cornea deteriorates further, because the epithelium is poorly maintained and limbal blood vessels invade the stroma [6-8]. The adult $\mathrm{Pax}^{+/-}$ corneal epithelium is thin and fragile, cell turnover is elevated, centripetal movement is disrupted and goblet cells accumulate. The expression of keratin 12 (K12), which is regulated by Pax6 [9], is delayed and immunostaining is weak and patchy $[6-8,10,11]$. Indirect evidence suggests that reduced Pax6 causes LESC deficiency in both 
$P A X 6^{+/-}$humans and $\mathrm{Pax}^{+/-}$mice and this may underlie adult corneal deterioration $[1,12]$.

It is not known if all corneal abnormalities in adult $\mathrm{Pax6}^{+/-}$mice are predetermined by abnormal development or whether some are caused by reduced Pax6 in the adult. Our aim was to determine whether depletion of Pax6 in adult mice caused corneal abnormalities, comparable to those reported for $\mathrm{Pax}^{+/-}$mice. We used one experimental strategy to deplete Pax6 ubiquitously and another to deplete Pax6 in LESCs.

\section{Main text}

\section{Materials and methods}

Mice

To deplete Pax6 ubiquitously, CAG-CreER ${ }^{T g /-} ; P^{P a x} 6^{f l /+}$ mice were produced by crossing hemizygous CAGCreER ${ }^{T g /-}$ mice (formal transgene name: $\mathrm{Tg}$ (CAG-cre/ Esr1*)5Amc) [13] to heterozygous $\mathrm{Pax}^{f l /+}$ mice (formal name: $\mathrm{Pax}^{\text {tmlLed/+}}$ ) [14]. Superscript symbols ' $T g /{ }^{-}$ and ' $-/-$ ' are used to distinguish hemizygous CAG-Cre$\mathrm{ER}^{\mathrm{Tg} /-}$ mice and non-transgenic CAG-CreER ${ }^{-/-}$siblings.

Keratin 19 (Krt19 gene; K19 protein) is expressed in the basal epithelium of the mouse limbus and conjunctiva but not the cornea [15]. To try to target LESCs in the limbal epithelium, Krt19-CreER ${ }^{T g /-} ; \operatorname{Pax}^{f l /+}$ mice were produced by crossing hemizygous $\mathrm{Krt19}$-CreER ${ }^{T g /-}$ mice (formal transgene name: $\operatorname{Krt1} 9^{\text {tm1(cre/ERT)Ggu}) ~[16] ~ t o ~ h e t-~}$ erozygous $\operatorname{Pax} 6^{f l+}$ mice.

RCE:loxP mice have the R26R CAG-boosted EGFP (RCE) reporter allele with an upstream loxPflanked STOP cassette (formal transgene name:

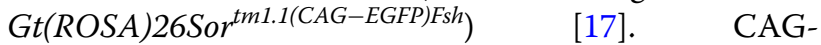
$\mathrm{CreER}^{T g /-}$;RCE:loxP mice with tamoxifen-inducible expression of GFP were bred by crossing CAG-CreER ${ }^{T g /-}$ and RCE:loxP mice. Krt19-CreER ${ }^{T g /-}$;RCE:loxP mice were bred by crossing Krt19-CreER ${ }^{T g /-}$ and RCE:loxP mice.

Mice were maintained on a predominantly CBA/ Ca genetic background and genotyped by PCR [13, 14, 16]. Some additional samples from mice on a CD-1 or $(\mathrm{C} 57 \mathrm{BL} / 6 \times \mathrm{CBA} / \mathrm{Ca}) \mathrm{F} 1$ genetic background from other studies $[18,19]$, were also analysed.

To activate CreER in adult mice, tamoxifen (SigmaAldrich) was freshly prepared in corn oil $(25-40 \mathrm{mg} /$ ml) by sonication in a $40{ }^{\circ} \mathrm{C}$ water bath and adjusted to $100 \mu \mathrm{g} / \mathrm{g}$ body weight in $0.1 \mathrm{ml}$. Mice of both sexes were injected intraperitoneally with tamoxifen at 12 weeks on 5 consecutive days and analysed 3 days later (no chase group) or after chase periods of 6 or 12 weeks. Control mice were injected with $0.1 \mathrm{ml}$ corn oil. Mice were culled by cervical dislocation, following overdose of gaseous halothane, and eyes were enucleated. Procedures for the induction of Cre expression in embryos at embryonic day
(E) 9.5 and the subsequent collection of E13.5 fetal samples are described elsewhere [19]. Tamoxifen treatment causes CreER to move to the nucleus and recombine loxP sites to convert the functional $\operatorname{Pax} 6^{f l}$ floxed allele to a $P a x 6^{\Delta}$ null allele or express the GFP lineage marker in the target cells and their progeny. This should occur in all cell types in CAG-CreER ${ }^{T g /-}$ mice, because CreER is expressed ubiquitously from the CAG promoter, but only in specific cell types in $\mathrm{Krt19-CreER^{Tg/- }}$ mice.

\section{Analysis}

Tissue samples were fixed in $4 \%$ paraformaldehyde overnight at $4{ }^{\circ} \mathrm{C}$. Fetal heads were processed to OCT compound and stored frozen before cryosections were cut and stained with haematoxylin and eosin (H\&E) $[19,20]$. Adult eyes were processed to paraffin wax, then $7 \mu \mathrm{m}$ sections were cut, mounted on glass slides and stained with H\&E or periodic acid-Schiff (PAS) stain [20]. Stained sections were photographed and measured using a Zeiss Axioplan-2 microscope and calibrated Zeiss Axiovision 4.8 digital camera system. Numerical data are included in Additional file 1 and measurements were compared by Student's t-test.

Immunohistochemistry methods are described elsewhere [20]. Briefly, wax sections, mounted on glass slides were heat-treated to unmask antigens, then incubated with blocking serum, followed by primary antibody, biotinylated secondary antibody, avidin-biotin reagent and 3,3'-diaminobenzidine (DAB) stain. Sections were then lightly counterstained with haematoxylin, dehydrated and slides were mounted with DPX mounting medium under coverslips. Negative control slides were treated with blocking serum instead of primary antibody. The antibodies used for Pax6 and K12 immunostaining were as described elsewhere [20], except that the secondary antibody was biotinylated rabbit anti-mouse, diluted 1:200 (E0433 from Dako, Ely, UK). For GFP immunostaining, the primary antibody was rabbit anti-GFP diluted 1:500 (ab290 from Abcam, Cambridge, UK) and the secondary antibody was biotinylated goat anti-rabbit, diluted 1:200 (Sc-2012 from SantaCruz Biotechnology, Heidelberg, Germany).

\section{Results}

\section{Ubiquitous depletion of Pax6 in embryos}

For another study, CAG-CreER ${ }^{T g /-} ; P a x 6^{f l / f l}$ and CAGCreER ${ }^{T g /-} ; \mathrm{Pax}^{f l+}$ embryos were exposed to tamoxifen at E9.5 and culled at E13.5 [19]. By E13.5 tamoxifentreated CAG-CreER ${ }^{T g /} ;{ }^{\text {Pax }} 6^{f l / f l}$ fetuses (with two floxed $\operatorname{Pax}^{f l}$ alleles) had smaller eyes and lenses than CAG-CreER ${ }^{T g /-} ; \operatorname{Pax}^{f l /+}$ fetuses (Additional file 1 and Additional file 2: Fig. S1). This showed that tamoxifenmediated depletion of Pax6 could affect eye development. 


\section{Ubiquitous depletion of Pax6 in adults}

The preliminary result with fetal eyes encouraged us to investigate whether tamoxifen-mediated, depletion of Pax6 in adults caused any corneal abnormalities, similar to those in $\mathrm{Pax6}^{+-}$mice, where Pax6 is low throughout development. Pax6-depletion in adults is unlikely to reproduce $\mathrm{Pax}^{+/-}$developmental defects but adult corneal deterioration could be mediated via Pax6-deficiency in adult LESCs, the LESC niche, the corneal epithelium or other ocular tissues $[5,10]$. We compared the effects of tamoxifen treatment of CAG-CreER ${ }^{T g /-} ; P{ }^{2} 6^{f l+}$ mice to several genotype and treatment controls, which were included to control for any unexpected effects of the CAG-CreER transgene or the floxed $\operatorname{Pax} 6^{f l}$ allele alone [20-24].

Following tamoxifen treatment at 12 weeks and a 6-week chase, Pax6 immunostaining was positive in the corneal epithelia of all the control combinations (Fig. 1ag). Although immunohistochemistry was not quantified,
Pax6 appeared to be weak and/or patchy in the corneal epithelia of CAG-CreER ${ }^{T g /-} ; \operatorname{Pax}^{f l /+}$ mice, treated with tamoxifen as adults (Fig. $1 \mathrm{~h}-\mathrm{l}$ ). However, eye and corneal morphology appeared grossly normal (apart from some processing artefacts), with no blood vessels visible in the cornea (Fig. 2). PAS-positive goblet cells were not detected in the corneal epithelium (data not shown) and there was little or no effect on K12 staining (Fig. 1m-t). Similar results were obtained after a 12-week chase and, again, corneal morphology appeared grossly normal (Fig. 3). For comparison, previously published corneal histology and immunostaining are shown for wild-type $\mathrm{Pax}^{+/+}$and heterozygous $\mathrm{Pax}^{+/-}$eyes in Additional file 2: Fig. S2. GFP immunostaining of eyes from tamoxifen-treated CAG-CreER ${ }^{T g /-}$;RCE:loxP reporter mice showed mosaic expression in the corneal epithelium (Additional file 2: Fig. S3).

We did not include CAG-CreER ${ }^{T g /-} ; \operatorname{Pax}^{f l / f l}$ mice, with two floxed $\operatorname{Pax}^{f l}$ alleles, in the main study because

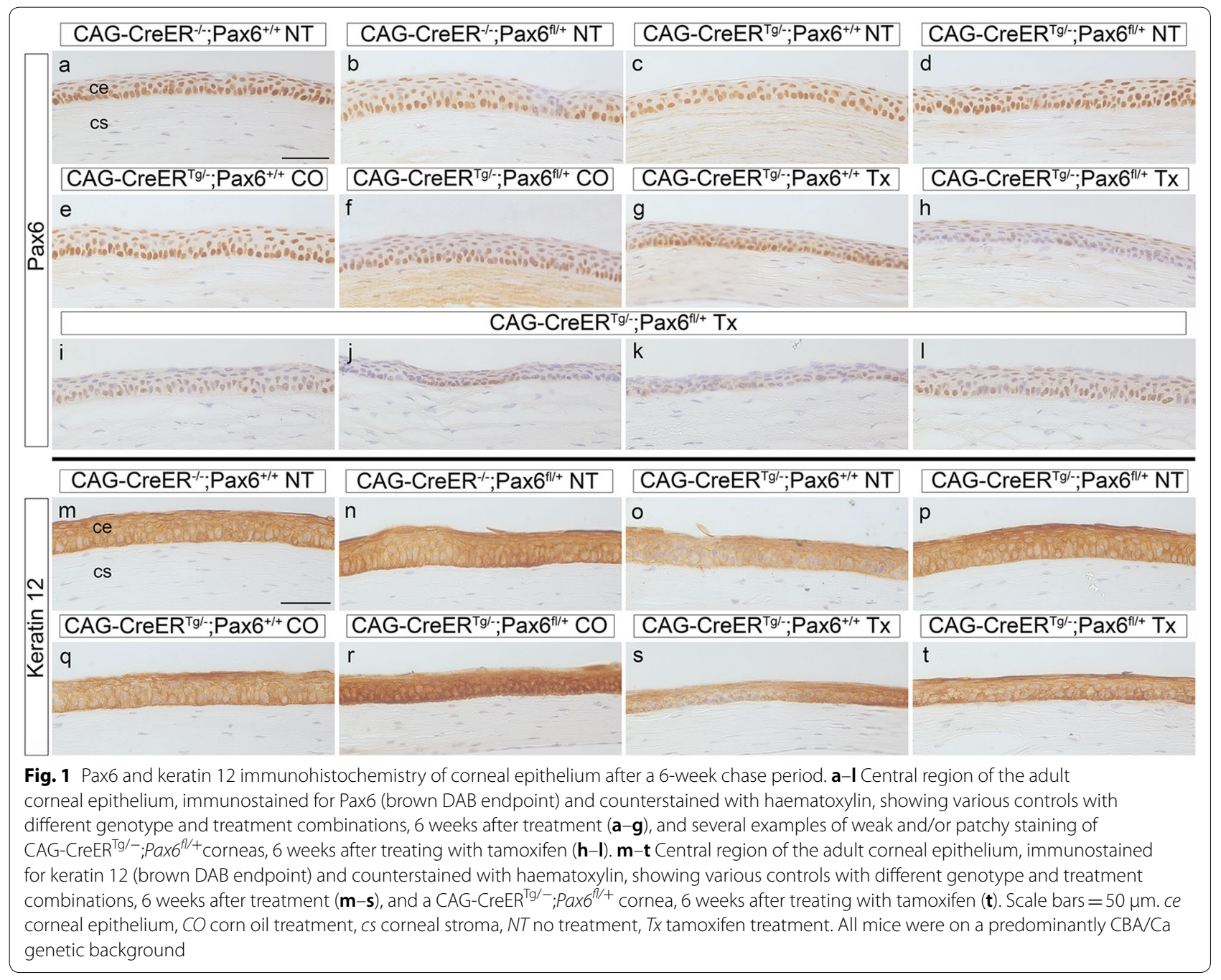




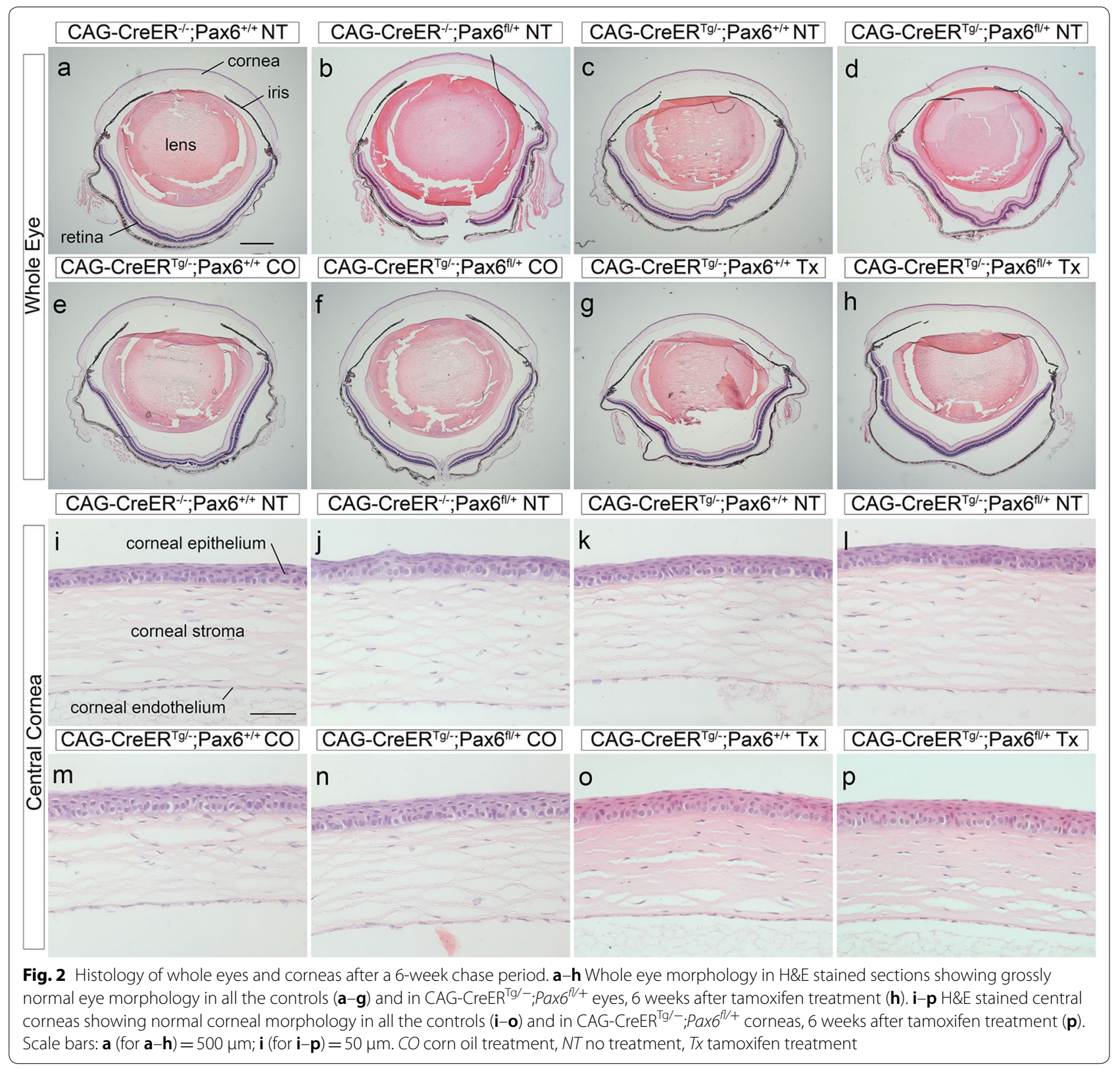

severe, global depletion of Pax6 in these mice results in diabetes [18]. However, Pax6 immunostaining of corneas from CAG-CreER ${ }^{T g /-} ; \operatorname{Pax}^{f l f l}$ mice, produced for another study [18], showed that Pax6 protein was not eliminated following tamoxifen treatment and a 6-week chase period (Additional file 2: Fig. S4).

\section{Targeting Pax6-depletion to LESCs}

To try to deplete Pax6 in LESCs we treated Krt19CreER ${ }^{T g /-} ; \operatorname{Pax}^{f l /+}$ mice with tamoxifen at 12 weeks and analysed the results after a 12 -week chase period, to allow sufficient time for treated LESCs to replenish the corneal epithelium. Pax6 and K12 staining appeared normal and no corneal morphological abnormalities were seen (Additional file 2: Fig. S5). Tamoxifen-treated Krt19$\mathrm{CreER}^{\mathrm{Tg} /-} ; \mathrm{RCE}:$ loxP reporter mice produced patchy GFP reporter immunostaining in the conjunctiva, some sparse staining in the limbus but no staining in the corneal epithelium (Additional file 2: Fig. S6).

\section{Discussion}

Tamoxifen treatment to deplete Pax6 in E9.5 CAGCreER ${ }^{T g /-} ; P{ }^{2} 6^{f l f l}$ embryos affected eye morphology by E13.5 but did not prevent lens development. The lens 


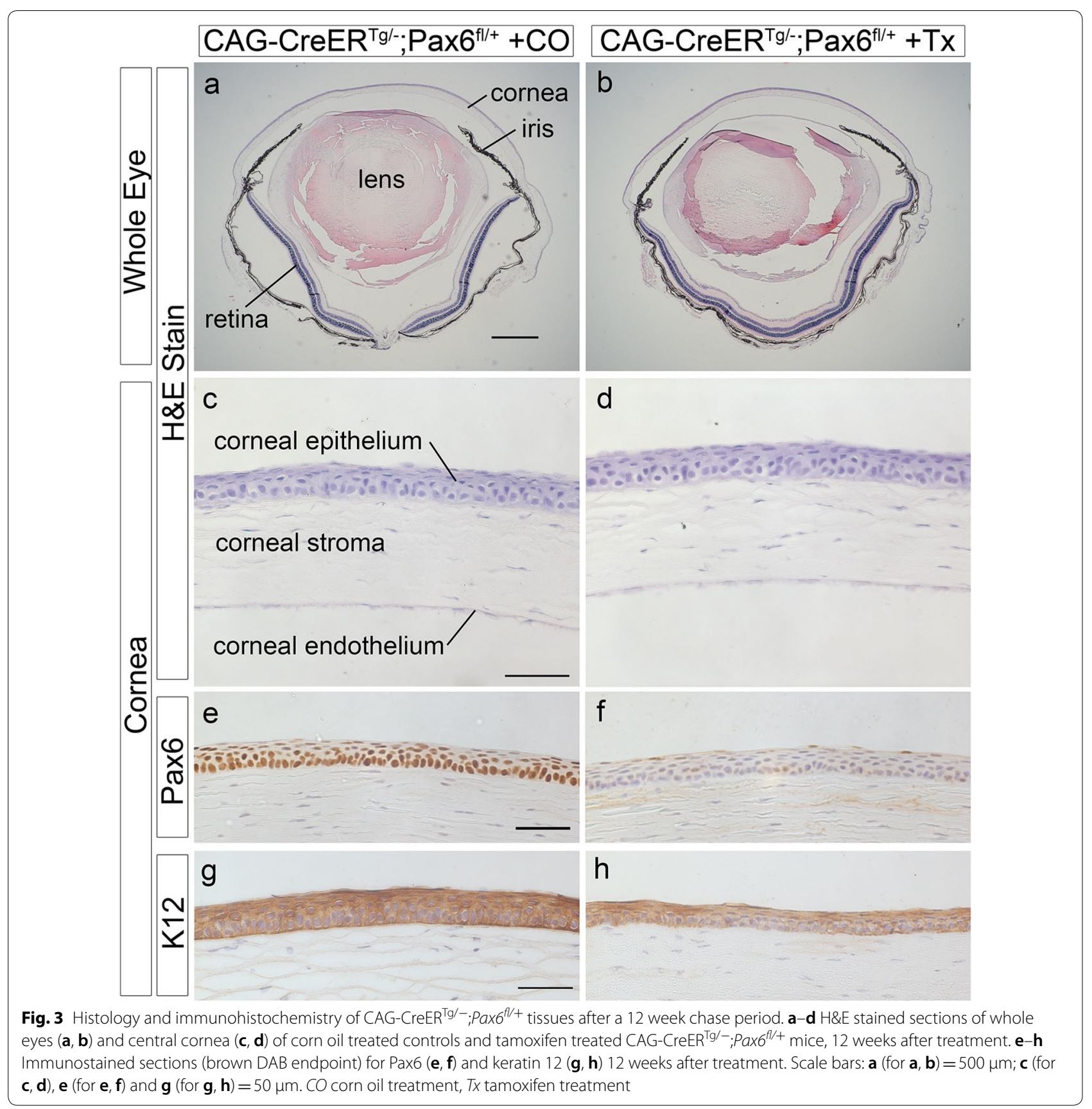

placode forms around E9.5 and is absent in $\mathrm{Pax6}^{-/-}$ homozygotes [25], so E9.5 tamoxifen-treatment was probably too late to prevent lens development in the CAG-CreER ${ }^{T g /-}$;Pax $6^{f l / f l}$ embryos but we did not investigate whether any Pax6 remained at E13.5.

As tamoxifen treatment of $\mathrm{Krt19-CreER^{Tg } / -}$;RCE:loxP mice did not produce any GFP-positive corneal epithelial cells after a 12-week chase, it is likely that this strategy failed to target LESCs. With hindsight, the Krt14-Cre$\mathrm{ER}^{T g /-}$ mouse may have been more suitable for targeting expression to LESCs, as this has been successful in lineage tracing experiments $[26,27]$.

The normal corneal morphology of the tamoxifentreated adult CAG-CreER ${ }^{T g /-} ; \operatorname{Pax}^{f l /+}$ mice is consistent with the possibility that normal Pax6 levels are not required in the adult to maintain the corneal epithelium. This would suggest that deterioration of the adult $\mathrm{Pax}^{+/-}$corneal epithelium was predetermined during development. However, we also need to consider technical explanations for our results, particularly as corneal 
effects of Pax6-deficiency have now been corrected successfully in adult mice $[28,29]$.

One possibility is that our investigation was undermined by mosaic deletion of the $\operatorname{Pax}^{f l}$ allele. The presence of some Pax6-positive cells in the corneal epithelia of tamoxifen-treated CAG-CreER ${ }^{T g /-} ; \operatorname{Pax}^{f l / f l}$ mice suggests that mosaicism occurred in these mice as well as CAG-CreER ${ }^{T g /-}$;RCE:loxP reporter mice. We, therefore, suggest that mosaic $\operatorname{Pax}^{f l}$ deletion was caused by mosaic CAG-CreER ${ }^{T g}$ transgene expression but recombination of $\operatorname{Pax}^{f l}$ loxP sites could also be inefficient for other reasons. Mosaic $\operatorname{Pax}^{f l}$ deletion would lead to a mixture of $\operatorname{Pax}^{\Delta / \Delta}, \operatorname{Pax}^{f / \Delta}$ and $\operatorname{Pax} 6^{f / f l}$ cells in CAG$\mathrm{CreER}^{\mathrm{Tg} /-} ; \mathrm{Pax}^{f / f l}$ mice or a mixture of $\operatorname{Pax}^{\Delta /+}$ and $\operatorname{Pax}^{f /+}$ cells in CAG-CreER ${ }^{T g /-} ; \operatorname{Pax} 6^{f /+}$ mice.

The effects of mixtures of wild-type and $\mathrm{Pax}^{-1-}$ or $\mathrm{Pax}^{+/-}$cells, in ocular tissues, have been investigated using mouse chimaeras. Eye development was abnormal in $\mathrm{Pax}^{+/+} \leftrightarrow \mathrm{Pax}^{-/-}$chimaeras [30-33] but $\mathrm{Pax}^{+/+} \leftrightarrow \mathrm{Pax}^{+/-}$chimaeras had normal eyes $[5,10,33]$ with normal corneal morphology [10]. It was suggested that unknown signals from wild-type cells in the cornea and/or other ocular tissues might rescue the $\mathrm{Pax6}^{+/-}$ cells [10]. This might also occur in tamoxifen-treated CAG-CreER ${ }^{\mathrm{Tg} /-} ; \mathrm{Pax}^{f / /+}$ corneas if the conditional $\operatorname{Pax}^{f l}$ allele is not deleted in all cells.

Although the corneal epithelia of tamoxifen-treated CAG-CreER ${ }^{T g /-} ; \operatorname{Pax}^{f l / f l}$ mice contained many Pax6positive cells (Additional file 2: Fig. S4), no Pax6 protein was detected by immunofluorescence in most pancreatic islet cells in equivalent mice from the same study [18]. Apparent differences in frequencies of Pax6-positive cells between these two tissues may reflect genuine biological differences rather than technical differences in detecting Pax6-positive cells. Mosaic CAG-CreER ${ }^{T g}$ expression might be more common and/or recombination of loxP sites less efficient in the corneal epithelium than pancreatic islets, resulting in mosaic $\operatorname{Pax} 6^{f l}$ deletion in the cornea.

Mosaic reporter expression also occurred in the corneal epithelium of CAG-CreER;R26R-LacZ and CAGCreER;R26R-mT/mG reporter mice in a lineage-tracing experiment [34]. This lineage tracing experiment was undertaken after the present study and, with hindsight, it would be worth investigating whether mosaic transgene expression is more common for specific tissues and/or specific CAG-CreER;loxP combinations.

\section{Limitations}

We evaluated corneal histology, the absence of goblet cells and K12 immunohistochemistry. Future investigations could include additional endpoints and markers.
In lineage-tracing experiments, labelled cells produced by tamoxifen-treated LESCs took at least 14 weeks to replace the whole corneal epithelium [26, $27,34]$. Thus, although our chase time of 12 weeks should have identified corneal defects attributable to Pax6-depletion in LESCs or the niche, it might not have been sufficient to produce the maximum effects.

We did not investigate how effectively Pax6 protein was depleted in other CAG-CreER ${ }^{T g /-} ; \mathrm{Pax}^{f l /+}$ ocular tissues or whether mosaic transgene expression occurred in those tissues. Also, DNA or RNA methods were not used to confirm that at least some floxed $\operatorname{Pax}^{f l}$ alleles were converted to $\operatorname{Pax}^{\Delta}$ in the corneal epithelium.

\section{Additional files}

Additional file 1. Fetal eye measurements

Additional file 2: Fig S1. E13.5 fetal eye morphology following tamoxifen treatment at E9.5. Fig. S2. Previously published histology and immunohistochemistry of adult wild-type and heterozygous Pax ${ }^{+/-}$mouse eyes. Fig. S3. Expression of GFP reporter in corneal epithelium of CAGCreER ${ }^{\mathrm{Tg} /}$; RCE:loxP mice after tamoxifen treatment and different chase periods. Fig. S4. Pax6 immunohistochemistry of CAG-CreER ${ }^{T g /-} ; P \times 6^{f / 4}$ and CAG-CreER ${ }^{\mathrm{Tg} /} ;{ }^{\text {Pax }} 6^{\text {fl/fl }}$ corneal epithelia after a 6-week chase period. Fig. S5. Histology and immunohistochemistry of Krt19-CreER ${ }^{\top \mathrm{Tg} /}-\mathrm{Pax} 6^{f / /+}$ tissues after a 12 week chase period. Fig. S6. Expression of GFP reporter in corneal epithelium of Krt19-CreER ${ }^{T g /-}$; RCE:/oxP mice after tamoxifen treatment and different chase periods.

\section{Abbreviations}

DAB: 3,3'-diaminobenzidine; DPX: distyrene plasticizer xylene; E: embryonic day; EGFP: enhanced green fluorescent protein; GFP: green fluorescent protein; H\&E: haematoxylin and eosin; K12: keratin 12; K19: keratin 19; LESC: limbal epithelial stem cell; OCT compound: optimal cutting temperature compound; PAS: periodic acid-Schiff; TAC: transient (or transit) amplifying cell.

\section{Authors' contributions}

NJD produced and analysed the results, produced the figures and wrote most of the first draft. MM and DJK provided samples, produced in other studies, for evaluation. DJP designed and supervised the study that provided tamoxifentreated embryos. JMC and REH designed and supervised part of the main study. JDW designed and supervised part of the main study and wrote part of the manuscript. All authors read and approved the final manuscript.

\footnotetext{
Author details

${ }^{1}$ Centre for Integrative Physiology, Biomedical Sciences, University of Edinburgh Medical School, Hugh Robson Building, George Square, Edinburgh EH8 9XD, UK. ${ }^{2}$ Centre for Discovery Brain Sciences, Biomedical Sciences, University of Edinburgh Medical School, Hugh Robson Building, George Square, Edinburgh EH8 9XD, UK. ${ }^{3}$ Medical and Developmental Genetics Section, MRC Human Genetics Unit, MRC IGMM, University of Edinburgh, Western General Hospital, Crewe Road, Edinburgh EH4 2XU, UK. ${ }^{4}$ School of Medicine, Medical Sciences and Nutrition, Institute of Medical Sciences, University of Aberdeen, Foresterhill, Aberdeen AB25 2ZD, UK. ${ }^{5}$ Centre for Integrative Physiology, Clinical Sciences, University of Edinburgh Medical School, Hugh Robson Building, George Square, Edinburgh EH8 9XD, UK. ${ }^{6}$ Present Address: Biology Teaching Organisation, University of Edinburgh, Ashworth Laboratories, Charlotte Auerbach Road, King's Buildings, Edinburgh EH9 3FL, UK. ${ }^{7}$ Present Address: Centre for Mammalian Synthetic Biology, University of Edinburgh, Roger Land Building, Alexander Crum Brown Road, King's Buildings, Edinburgh EH9 3FF, UK.
} 


\section{Acknowledgements}

We thank Prof. Veronica van Heyningen for providing us with samples for preliminary evaluation, Dr. Guoqiang Gu, Vanderbilt University, USA, for providing Krt19-CreER ${ }^{T g /}$ - mice, staff at BRR, University of Edinburgh for specialised technical services and Dr. Steven Morley for helpful comments on the manuscript.

\section{Competing interests}

The authors declare that they have no competing interests.

\section{Availability of data and materials}

The numerical data generated and analysed during this study are included in the additional information files of this published article.

\section{Consent for publication}

Not applicable.

\section{Ethics approval and consent to participate}

Mice were bred and maintained at the University of Edinburgh, UK. Animal work was approved by the University of Edinburgh Ethical Review Committee and performed in accordance with UK Home Office Regulations under UK Home Office licences PPL 60/3635 and PPL 60/4302. Samples produced in other studies were from mice regulated by UK Home Office licences PPL $60 / 3785$ and PPL 60/3913.

\section{Funding}

This work was supported by the Wellcome Trust (Grant 088876/Z/09/Z to JDW, REH and JMC). The funding body had no role in the design of the study, the collection, analysis and interpretation of data or the preparation of the manuscript.

\section{Publisher's Note}

Springer Nature remains neutral with regard to jurisdictional claims in published maps and institutional affiliations.

Received: 24 Auqust 2018 Accepted: 30 September 2018

Published online: 05 October 2018

\section{References}

1. Mort RL, Douvaras P, Morley SD, Dorà N, Hill RE, Collinson JM, West JD. Stem cells and corneal epithelial maintenance: insights from the mouse and other animal models. In: Kubiak JZ, editor. Results Probl Cell Differ, 55, "Mouse development: from oocyte to stem cells". Berlin: Springer; 2012. p. 357-94.

2. Shaham O, Menuchin Y, Farhy C, Ashery-Padan R. Pax6: a multi-leve regulator of ocular development. Prog Retin Eye Res. 2012;31(5):351-76.

3. Hill RE, Favor J, Hogan BLM, Ton CCT, Saunders GF, Hanson IM, Prosser J, Jordan T, Hastie ND, VanHeyningen V. Mouse small eye results from mutations in a paired-like homeobox-containing gene. Nature. 1991:354(6354):522-5

4. van Raamsdonk CD, Tilghman SM. Dosage requirement and allelic expression of PAX6 during lens placode formation. Development. 2000;127(24):5439-48

5. Collinson JM, Quinn JC, Buchanan MA, Kaufman MH, Wedden SE, West JD, Hill RE. Primary defects in the lens underlie complex anterior segment abnormalities of the Pax6 heterozygous eye. Proc Natl Acad Sci USA 2001;98(17):9688-93.

6. Davis J, Duncan MK, Robison WG, Piatigorsky J. Requirement for Pax6 in corneal morphogenesis: a role in adhesion. J Cell Sci. 2003:116(11):2157-67.

7. Ramaesh T, Collinson JM, Ramaesh K, Kaufman MH, West JD, Dhillon B. Corneal abnormalities in $\mathrm{Pax}^{+/-}$small eye mice mimic human aniridiarelated keratopathy. Invest Ophthalmol Vis Sci. 2003;44(5):1871-8.

8. Ramaesh T, Ramaesh K, Collinson JM, Chanas SA, Dhillon B, West JD. Developmental and cellular factors underlying corneal epithelial dysgenesis in the $\mathrm{Pax}^{+/-}$mouse model of aniridia. Exp Eye Res. 2005:81(2):224-35.

9. Liu JJ, Kao WWY, Wilson SE. Corneal epithelium-specific mouse keratin K12 promoter. Exp Eye Res. 1999;68(3):295-301.
10. Collinson JM Chanas SA, Hill RE, West JD Corneal development, limbal stem cell function, and corneal epithelial cell migration in the Pax6 $6^{+/-}$ mouse. Invest Ophthalmol Vis Sci. 2004:45(4):1101-8.

11. Douvaras P, Mort RL, Edwards D, Ramaesh K, Dhillon B, Morley SD, Hill RE, West JD. Increased corneal epithelial turnover contributes to abnormal homeostasis in the Pax6 $6^{+/-}$mouse model of aniridia. PLoS ONE. 2013:8(8):e71117.

12. Ahmad S. Concise review: limbal stem cell deficiency, dysfunction, and distress. Stem Cells Transl Med. 2012;1(2):110-5.

13. Hayashi S, McMahon AP. Efficient recombination in diverse tissues by a tamoxifen-inducible form of Cre: a tool for temporally regulated gene activation/inactivation in the mouse. Dev Biol. 2002;244(2):305-18.

14. Simpson TI, Pratt T, Mason JO, Price DJ. Normal ventral telencephalic expression of Pax6 is required for normal development of thalamocortical axons in embryonic mice. Neural Dev. 2009;4:19.

15. Yoshida S, Shimmura S, Kawakita T, Miyashita H, Den S, Shimazaki J, Tsubota K. Cytokeratin 15 can be used to identify the limbal phenotype in normal and diseased ocular surfaces. Invest Ophthalmol Vis Sci. 2006;47(11):4780-6.

16. Means AL, Xu YW, Zhao AZ, Ray KC, Gu GQ. A CK19 ${ }^{\text {CreERT knockin mouse }}$ line allows for conditional DNA recombination in epithelial cells in multiple endodermal organs. Genesis. 2008;46(6):318-23.

17. Miyoshi G, Hjerling-Leffler J, Karayannis T, Sousa VH, Butt SJB, Battiste J, Johnson JE, Machold RP, Fishell G. Genetic fate mapping reveals that the caudal ganglionic eminence produces a large and diverse population of superficial cortical interneurons. J Neurosci. 2010;30(5):1582-94.

18. Hart AW, Mella S, Mendrychowski J, van Heyningen V, Kleinjan DA. The developmental regulator Pax6 is essential for maintenance of islet cell function in the adult mouse pancreas. PLoS ONE. 2013;8(1):e54173.

19. Quintana-Urzainqui I, Kozić Z, Mitra S, Tian T, Manuel M, Mason JO, Price DJ. Tissue-specific actions of Pax6 on proliferation-differentiation balance in the developing forebrain are Foxg1-dependent. bioRxiv. 2018. https://doi.org/10.1101/374074.

20. Dorà NJ, Collinson JM, Hill RE, West JD. Hemizygous Le-Cre transgenic mice have severe eye abnormalities on some genetic backgrounds in the absence of loxP sites. PLoS ONE. 2014;9(10):e109193.

21. Schmidt-Supprian M, Rajewsky K. Vagaries of conditional gene targeting. Nat Immunol. 2007:8(7):665-8.

22. Harno E, Cottrell EC, White A. Metabolic pitfalls of CNS Cre-based technology. Cell Metab. 2013;18(1):21-8.

23. Dora NJ, Crookshanks AJF, Leung KKY, Simpson TI, Mason JO, Price DJ, West JD. Analysis of compound heterozygotes reveals that the mouse floxed Pax6 ${ }^{\text {tmived }}$ allele produces abnormal eye phenotypes. Transgenic Res. 2016;25(5):679-92.

24. Kristianto J, Johnson MG, Zastrow RK, Radcliff AB, Blank RD. Spontaneous recombinase activity of Cre-ERT2 in vivo. Transgenic Res. 2017;26(3):411-7.

25. Grindley JC, Davidson DR, Hill RE. The role of Pax-6 in eye and nasal development. Development. 1995:121:1433-42.

26. Di Girolamo N, Bobba S, Raviraj V, Delic NC, Slapetova I, Nicovich PR, Halliday GM, Wakefield D, Whan R, Lyons JG. Tracing the fate of limbal epithelial progenitor cells in the murine cornea. Stem Cells. 2015;33(1):157-69.

27. Amitai-Lange A, Altshuler A, Bubley J, Dbayat N, Tiosano B, ShalomFeuerstein R. Lineage tracing of stem and progenitor cells of the murine corneal epithelium. Stem Cells. 2015;33(1):230-9.

28. Gregory-Evans CY, Wang X, Wasan KM, Zhao J, Metcalfe AL, GregoryEvans K. Postnatal manipulation of Pax6 dosage reverses congenital tissue malformation defects. J Clin Invest. 2014;124(1):111-6.

29. Chen YT, Chen FYT, Vijmasi T, Stephens DN, Gallup M, McNamara NA. Pax6 downregulation mediates abnormal lineage commitment of the ocular surface epithelium in aqueous-deficient dry eye disease. PLoS ONE. 2013;8(10):e77286.

30. Quinn JC, West JD, Hill RE. Multiple functions for Pax6 in mouse eye and nasal development. Genes Dev. 1996;10(4):435-46.

31. Collinson JM, Hill RE, West JD. Different roles for Pax6 in the optic vesicle and facial epithelium mediate early morphogenesis of the murine eye. Development. 2000;127(5):945-56.

32. Collinson JM, Quinn JC, Hill RE, West JD. The roles of Pax6 in the cornea, retina, and olfactory epithelium of the developing mouse embryo. Dev Biol. 2003:255(2):303-12. 
33. Li S, Goldowitz D, Swanson DJ. The requirement of Pax6 for postnatal eye development: evidence from experimental mouse chimeras. Invest Ophthalmol Vis Sci. 2007;48:3292-300.

34. Dorà NJ, Hill RE, Collinson JM, West JD. Lineage tracing in the adult mouse corneal epithelium supports the limbal epithelial stem cell hypothesis with intermittent periods of stem cell quiescence. Stem Cell Res. 2015;15(3):665-77.
Ready to submit your research? Choose BMC and benefit from:

- fast, convenient online submission

- thorough peer review by experienced researchers in your field

- rapid publication on acceptance

- support for research data, including large and complex data types

- gold Open Access which fosters wider collaboration and increased citations

- maximum visibility for your research: over 100M website views per year

At BMC, research is always in progress.

Learn more biomedcentral.com/submissions 